УДК 351:338.24

(C) 2012

Мареніченко В. В., матістрант

Дніпропетровський державний аграрний університет

\title{
АНТИКРИЗОВЕ УПРАВЛІННЯ В СИСТЕМІ МАЛОГО ТА СЕРЕДНЬОГО БІЗНЕСУ
}

\section{Рецензент - доктор державного управління, професор В. В. Сиченко}

\begin{abstract}
Обгрунтовано актуальність дослідження антикризового управління в системі малого та середнього бізнесу Украӥни. Проаналізовано найбільші переваги малих та середніх підприємств. Досліджено антикризові заходи, які слід впроваджувати на рівні держави. Виявлено найбільш вразливі сфери діяльності на підприємстві, де слід застосовувати заходи попередження і протидії кризових явищ. Визначено чинники впливу на занепад малого та середнього бізнесу й розроблено систему антикризових заходів, як механізм підвищення ефективності діяльності підприємства.
\end{abstract}

Ключові слова: криза, антикризове управління, малий та середній бізнес.

Постановка проблеми. Серед безлічі важливих питань державної політики та політики організації діяльності на підприємстві постають особливо актуальні питання формування середнього класу в Україні, а також протидії кризовим явищам у підприємницькому секторі. На перший погляд, у цих питаннях немає нічого спільного, однак проведене дослідження характеризує особливу взаємодію окреслених питань.

Даний аспект є особливо актуальним як для власників малого та середнього бізнесу України, так i для держави в цілому. Проблема антикризового управління в малому та середньому бізнесі в мікроекономічному аспекті грунтується, в першу чергу, на основі фінансової стабілізації підприємства за рахунок забезпечення фінансової рівноваги, підтримання фінансової стійкості та усунення неплатоспроможності. На рівні держави, у макроекономічному аспекті, - це створення передумов для стабільного функціонування підприємств цього сектора економіки, насамперед, через податкову i грошово-кредитну політику.

Аналіз основних досліджень і публікацій, у яких започатковано розв'язання проблеми. Питаннями формування середнього класу в Україні, форм розвитку й функціонування малого та середнього підприємництва, а також їх антикризового управління займалося чимало науковців і вчених, зокрема такі, як М. Білик, В. Василенко, Є. Головаха, Е. Лібанова, І. Медведен- ко, І. Неделько, О. Піскунова, С. Реверчук, В. Савченко, О. Травянко та інші.

Розробки зазначених фахівців переважно грунтуються на необхідності оптимізації фінансових ресурсів бізнес-структури. Виходячи 3 даної ситуації, розглядаються можливі шляхи здійснення антикризової політики. Водночас, не дивлячись на різноманіття наукової полеміки, продовжується пошук оптимальних варіантів здійснення антикризових заходів. Нині бракує наукових праць, які б мали безпосереднє впровадження в реальному секторі економіки.

Мета і завдання дослідження. Метою дослідження $\epsilon$ пошук ефективного механізму антикризового управління в системі малого та середнього бізнесу.

Завданнями дослідження $є$ визначення чинників впливу на занепад підприємств малого та середнього бізнесу в умовах кризи й розробка антикризових заходів на підприємстві реального сектора економіки.

Матеріали і методи досліджень. Аналіз літературних джерел допоміг згрупувати чинники впливу на занепад малого та середнього бізнесу в Україні, дослідити й охарактеризувати заходи протидії кризовим явищам і розробити дієву систему антикризових заходів на сільськогосподарському підприємстві.

Середній клас, безсумнівно, є важливою частиною розвитку демократичної держави. Про це свідчить досвід економічно розвинутих країн світу, в яких він є основою і соціальною базою. Саме середній клас - це ключ до демократичних перетворень, активна частина суспільства, переважаюча кількісно й якісно. Світова спільнота виділяє юридичну свободу, політичну рівність та громадську спільність як характерні ознаки середнього класу.

Саме розвиток малого та середнього бізнесу $\epsilon$ фундаментом для створення середнього класу в будь-якому ринково-демократичному суспільстві.

Малі та середні підприємства, порівняно 3 великими, є досить гнучкими, такими, що динамічно розвиваються, схильні до швидкої диверси- 


\section{СТОРІНКА МОЛОДОГО ВЧЕНОГО}

фікації. Крім того саме вони в значно більшій мірі, ніж великі, займаються інноваційним бізнесом. Саме в системі малого та середнього бізнесу розв'язуються найбільш важливі соціальноекономічні проблеми, у тім числі - безробіття. Врешті-решт малий та середній бізнес - це реальний шанс для молодого покоління 3 новітнім мисленням й абсолютно радикальним світоглядом проявити себе у повній мірі [3].

У процесі дослідження виявлено численні чинники впливу на занепад малого та середнього бізнесу, до яких відносяться:

1.) Екзогенні:

- нестабільність національної економіки, надмірна їі політизованість;

- невідповідність законодавчої бази, зокрема в питаннях оподаткування;

- світова економічна криза.

2.) Ендогенні:

- необгрунтованість економічних рішень вищого керівництва (зазвичай керівники малих та середніх підприємств - це новачки у справі підприємництва);

- проблеми 3 підбором персоналу (малий та середній бізнес не в змозі конкурувати з великим на ринку праці у плані найму висококваліфікованих працівників);

- відсутність стратегічного мислення у підприємців.

Досліджуючи загальну систему функціонування малих і середніх підприємств в умовах світової фінансової кризи, сформовано основні заходи протидії кризовим явищам.

По-перше, на рівні підприємства:

- трансформація низькооборотних активів у високооборотні;

- усунення зовнішніх факторів банкрутства;

- прогнозування фінансових результатів діяльності, рентабельності тощо;

- розробка моделей фінансового стану підприємства (різні варіації використання ресурсів, персоналу, інвестицій тощо);

- проведення ресурсоощадних заходів, впровадження новітніх технологій.

По-друге, на рівні держави:

- розробка нових нормативно-правових актів для мінімізації наслідків кризи;

- налагодження кредитної системи, забезпечення виконання інвестиційних проектів;

- реформування національної системи освіти, забезпечення молоді відповідною кваліфікацією для забезпечення зростання підприємницького сектора [2].

Виходячи 3 цього, стає очевидним, що вико- ристовуючи описані заходи та методи подолання фінансової кризи, стане можливим мінімізувати негативний вплив кризових явищ на малий та середній бізнес, зберегти старі й створити нові робочі місця, за рахунок чого отримати заплановані та додаткові надходження до бюджету.

Результати досліджень. Впровадження антикризових заходів на підприємствах малого і середнього бізнесу слід визначати на основі проведення діагностики фінансового стану.

Результатом діагностики фінансового стану підприємства є визначення техніко-економічних показників діяльності підприємства, аналіз ліквідності балансу, платоспроможності підприємства, оцінка структури балансу, показників ділової активності, ймовірності банкрутства [1].

Дослідження фінансово-економічних показників діяльності підприємств малого та середнього бізнесу, а також врахувавши тенденції розвитку бізнес-середовища в Україні, дали змогу розробити систему варіантів прийняття управлінських рішень в якості ефективного механізму попередження та подолання кризових явищ на підприємстві (див. табл.).

Отже, стає все більш очевидним, що запровадження антикризового управління на підприємстві в сучасних умовах $є$ необхідністю. Проте не слід також забувати, що криза - це не лише загроза, а й перспективна можливість. Небезпека кризи грунтується на тому, що підприємство більше не може вести узвичаєний спосіб життя, в той час, як можливість - це шанс досягнення конкурентних переваг, більшої ефективності й успішної діяльності на основі досягнення високого рівня прибутку.

Тому для запобігання кризі, ii подолання, а також перетворення iï негативних сторін на позитивні нами й була запропонована система антикризових заходів, що обгрунтовує нові можливості для підприємства.

\section{Висновки:}

1. До основних завдань антикризового управління на підприємстві належить визначення загальних показників діяльності, аналіз ліквідності балансу, платоспроможності підприємства, оцінка структури балансу, показників ділової активності, ймовірності банкрутства, а також на їх основі розробка та впровадження антикризових заходів із метою подолання нестабільності й поліпшення роботи підприємства.

2. Впровадження антикризових заходів на підприємстві має грунтуватися 3 погляду забезпечення ефективності діяльності в таких сферах: 
СТОРІНКА МОЛОДОГО ВЧЕНОГО

Система варіантів прийняття управлінських рішень

\begin{tabular}{|c|c|c|}
\hline $\begin{array}{l}\text { Управлінські } \\
\text { рішення }\end{array}$ & Варіант рішення (антикризовий захід) & Можливий результат \\
\hline \multirow{5}{*}{ 1. Традиційні } & Мінімізація чисельності працівників & Економія фонду оплати праці \\
\hline & Оптимізація основних фондів & $\begin{array}{c}\text { Виникнення додаткових фінансових } \\
\text { ресурсів }\end{array}$ \\
\hline & $\begin{array}{c}\text { Реалізація дебіторської } \\
\text { заборгованості }\end{array}$ & $\begin{array}{c}\text { Підвищення ліквідності, вивільнення } \\
\text { інвестиційних ресурсів }\end{array}$ \\
\hline & $\begin{array}{c}\text { Реструктуризація кредиторської } \\
\text { заборгованості }\end{array}$ & Зміна графіка платежів по кредитам \\
\hline & Цінове регулювання & $\begin{array}{c}\text { Збільшення обсягів збуту в необхідний } \\
\text { термін } \\
\end{array}$ \\
\hline \multirow{4}{*}{$\begin{array}{l}\text { 2. Інноваційно- } \\
\text { інвестиційні }\end{array}$} & $\begin{array}{l}\text { Впровадження новітніх технологій } \\
\text { (нова техніка, матеріальні ресурси, } \\
\text { альтернативні джерела енергії тощо) }\end{array}$ & $\begin{array}{c}\text { Підвищення ефективності виробництва, } \\
\text { прибутковості }\end{array}$ \\
\hline & $\begin{array}{c}\text { Проведення навчання персоналу на } \\
\text { основі бізнес-тренінгів, ділових ігор, } \\
\text { мозкового штурму, застосування } \\
\text { коучінгу тощо }\end{array}$ & $\begin{array}{c}\text { Підвищення мотивації персоналу, що } \\
\text { забезпечує підвищення ефективності } \\
\text { роботи }\end{array}$ \\
\hline & $\begin{array}{c}\text { Автоматизація та комп’ютеризація } \\
\text { підприємства }\end{array}$ & $\begin{array}{c}\text { Оптимізація інформаційних ресурсів і } \\
\text { підвищення ефективності користування } \\
\text { ними }\end{array}$ \\
\hline & $\begin{array}{l}\text { Налагодження проектної роботи } \\
\text { (створення проектів, що мають } \\
\text { визначені терміни й ресурси) }\end{array}$ & $\begin{array}{c}\text { Залучення додаткового капіталу, } \\
\text { створення нового, прогресивного виду } \\
\text { діяльності } \\
\end{array}$ \\
\hline
\end{tabular}

виробництво (удосконалення технологічного процесу), маркетинг (управління ціноутворенням, збутом, рекламою), фінанси (управління грошовими потоками, вартістю бізнесу), менеджмент (постійне навчання персоналу, удосконалення організаційної й управлінської структури), інвестиційна (залучення нових і ефективна співпраця зі старими інвесторами) й інноваційна (застосування нових технологій, орієнтація на

\section{БІБЛІОГРАФІЯ}

1. Василенко В. Антикризове управління підприємством: Навчальний посібник. - К. : ЦУЛ, 2003. $-378 \mathrm{c}$.

2. Піскунова О. Аналіз та оцінка фінансових ризиків діяльності малих підприємств // Фінанси України. - К., 2007. - 8. - С. 119-129. екологічність бізнесу) діяльність.

3. У результаті проведених нами досліджень визначено, що існує велика різноманітність варіантів прийняття управлінських рішень залежно від ситуації, що склалася на підприємстві, а саме - традиційні та інноваційно-інвестиційні. На основі аналізу сформовано систему варіантів прийняття управлінських рішень для застосування в різних сферах діяльності підприємства.

3. Травянко $O$. Особливості розвитку малих форм господарювання на регіональному рівні // Вісник Національної академії державного управління при Президентові України. - 2005. № 2. - C. 275-279. 